Loyola University Chicago, School of Law LAW eCommons

Faculty Publications \& Other Works

2005

\title{
Class Action Settlements: An Opt-in Proposal
}

John Bronsteen

Loyola University Chicago, School of Law, jbronst@luc.edu

Follow this and additional works at: http://lawecommons.luc.edu/facpubs

Part of the Criminal Law Commons

\section{Recommended Citation}

Bronsteen, John Class Action Settlements: An Opt-in Proposal, 2005 U. Ill. L. Rev. 903 (2005).

This Article is brought to you for free and open access by LAW eCommons. It has been accepted for inclusion in Faculty Publications \& Other Works by an authorized administrator of LAW eCommons. For more information, please contact law-library@luc.edu. 


\section{CLASS ACTION SETTLEMENTS: AN OPT-IN PROPOSAL}

John Bronsteen*

The outcome of a class action binds all class members except the few who take the trouble to opt out. This default rule enables plaintiffs' lawyers and defendants to settle class lawsuits on mutually beneficial terms that exploit class members. Judges approve such settlements because, among other things, they have a strong incentive to clear their dockets. This article suggests changing the default rule so that class settlements include only those who expressly assent to the terms of the settlement by opting in. This change would be aimed at removing the incentive to settle collusively, discouraging frivolous class lawsuits, and rewarding those plaintiffs who have the most meritorious claims.

\section{INTRODUCTION}

A class action is perhaps the most powerful tool that plaintiffs can wield. ${ }^{1}$ It threatens defendants with the prospect of enormous judgments against them, ${ }^{2}$ and it attracts the best plaintiffs' lawyers to pursue those judgments. ${ }^{3}$ By pooling the claims of thousands or even millions of people, it evens the playing field between individuals and the corporations they accuse of wrongdoing. ${ }^{4}$

* Assistant Professor, Loyola University Chicago School of Law. I thank Bruce Ackerman, Douglas Baird, Mary Anne Case, Adam Cox, Elizabeth Emens, Richard Epstein, Owen Fiss, Douglas Ginsburg, Philip Hamburger, Jenia Iontcheva, Richard Nagareda, Eric Posner, and Lior Strahilevitz for their helpful comments.

1. See, e.g., Guy Halfteck, The Class Action as a Financial Call Option 3 (Harvard Law and Economics Discussion Paper No. 466) (2004), available at http://ssrn.com/abstract=528043.

2. See Lester Brickman, ABA Regulation of Contingency Fees: Money Talks, Ethics Walks, 65 FORDHAM L. REV. 247, 277 (1996) ("By amassing thousands, tens of thousands, and even hundreds of thousands of claims in class actions, plaintiff lawyers have so changed the dynamics of tort litigation as to be able to extract multi-million-dollar and billion-dollar settlements ....").

3. See Kermit Roosevelt III, Defeating Class Certification in Securities Fraud Actions, 22 REV. LITIG. 405, 410 (2003).

4. See Deposit Guar. Nat'l Bank v. Roper, 445 U.S. 326, 339 (1980) ("Where it is not economically feasible to obtain relief within the traditional framework of a multiplicity of small individual suits for damages, aggrieved persons may be without any effective redress unless they may employ the class-action device."). 
Faced with this threat, a corporation typically will seek to settle the lawsuit rather than risk a crushing award of damages by a jury to the class. ${ }^{5}$ After the two sides negotiate the settlement, they send letters notifying the class members of the terms of the agreement. ${ }^{6}$ If a class member does not reply to the letter-and most do not ${ }^{7}$ - then the class member will be included in the settlement, ${ }^{8}$ receiving whatever the defendant has agreed to give her, and losing her right to bring her own lawsuit. ${ }^{9}$

This default rule gives rise to a problem that is widely bemoaned but, as yet, unsolved: a defendant often colludes with the lawyer for the plaintiffs to reach a settlement favorable to the colluders but unfavorable to the class members. ${ }^{10}$ Collusive settlements benefit the defendant (which insulates itself from future lawsuits by every class member) and the plaintiffs' lawyer (who receives a hefty fee while avoiding the time, expense, and uncertainty of a trial), but those settlements undercompensate the class members by giving them less than the expected value of the

5. Richard A. Nagareda, The Preexistence Principle and the Structure of the Class Action, 103 ColuM. L. REV. 149, 151 (2003) ("Settlements, not judgments after trial, stand overwhelmingly as the end result of actions certified to proceed on a classwide basis that are not resolved on dispositive motions." (citations omitted)).

6. Many class members probably never know that they are parties to a lawsuit at all. In some class actions (those filed under Rule 23(b)(1) or 23(b)(2)), the absent class members are not entitled to be notified of the lawsuit. FED. R. CIV.P. 23(c)(2)(A). In others (those filed under Rule 23(b)(3)), the absent class members must receive "the best notice practicable under the circumstances, including individual notice to all members who can be identified through reasonable effort." FED. R. CIV. P. $23(c)(2)(B)$. But even this requirement insures only that letters are sent to some class members. Some will be sent nothing; others will be sent a letter but will not receive it; and still others will receive a letter but discard it without reading it, much less understanding it.

7. E.g., Theodore Eisenberg \& Geoffrey P. Miller, The Role of Opt-Outs and Objectors in Class Action Litigation: Theoretical and Empirical Issues 22 (N.Y.U. Law \& Econ. Research Paper No. 04004, 2004), available at http://papers.ssm.com/abstract $=528146$.

8. E.g., Epstein v. MCA, Inc., 50 F.3d 644, 667 (9th Cir. 1995) ("[C]lass members, unlike individual litigants in traditional lawsuits, are bound by the settlement even though they do not individually consent to its terms."), overruled on other grounds sub nom. Matsushita v. Epstein, 516 U.S. 367 (1996); see also John C. Coffee, Jr., Class Action Accountability: Reconciling Exit, Voice, and Loyalty in Representative Litigation, 100 CoLUM. L. REV. 370, 381 (2000) ("Inevitably, some members of a large class will never receive notice and cannot therefore be assumed to have consented even though they will be bound by the judgment or settlement.").

9. See Patrick Woolley, Rethinking the Adequacy of Adequate Representation, 75 TEX. L. REV. 571,611 (1997) ("[A] settlement could be viewed as a forced sale of the right to litigate ...."); $c f$. Richard L. Marcus, They Can't Do That, Can They? Tort Reform Via Rule 23, 80 CORNELL L. REV. 858,892 (1995) ("[T]here appears to be no absolute bar to preclusion of claims by those who do not receive notice....").

10. John C. Coffee, Jr., Understanding the Plaintiff's Attorney: The Implications of Economic Theory for Private Enforcement of Law Through Class and Derivative Actions, 86 COLUM. L. REV. 669,714 (1986) ("'Often, the plaintiff's attorneys and the defendants can settle on a basis that is adverse to the interests of the plaintiffs. At its worst, the settlement process may amount to a covert exchange of a cheap settlement for a high award of attorney's fees. Although courts have long recognized this danger and have developed some procedural safeguards intended to prevent collusive settlements, these reforms are far from adequate to the task."); Nagareda, supra note 5, at 163 ("A staple of the class action literature is the recognition that class counsel might embrace a settlement inadequate for all, many, or some class members ...."). 
lawsuit. Perhaps more importantly, such settlements underdeter prospective defendants from breaking the law. ${ }^{11}$

There is wide agreement that this problem is both severe and prevalent. ${ }^{12}$ It has become the most important difficulty in the field of class actions. Indeed, it was perhaps the leading cause of the recent amendments to Rule 23 of the Federal Rules of Civil Procedure. ${ }^{13}$ Many commentators have urged judges to scrutinize class settlements more carefully, and to disallow the ones that dramatically underpay class members. ${ }^{14}$ The new amendments to Rule 23 adopt this approach. ${ }^{15}$ But the approach faces a daunting obstacle: judges' strong incentive to clear their dockets by approving these settlements. ${ }^{16}$ Disallowing a settlement creates the risk that the class action will go to trial, and class lawsuits are

11. E.g., Alon Harel \& Alex Stein, Auctioning for Loyalty: Selection and Monitoring of Class Counsel, 22 YALE L. \& POL'Y REV. 69, 71 (2004) ("This misalignment of interests between the class attorney and the class members is both manifestly unjust and inefficient. It is unjust because it does not provide adequate remedy to the victims of wrongs; it is inefficient because it dilutes the deterrence of corporate wrongdoers."); cf. Alexandra Lahav, Fundamental Principles for Class Action Governance, 37 IND. L. REV. 65, 70 (2003) ("There are two substantive justifications for permitting groups to litigate through the class action mechanism: compensation and deterrence.").

12. See, e.g., Susan P. Koniak \& George M. Cohen, In Hell There Will Be Lawyers Without Clients or Law, 30 HoFSTRA L. REV. 129, 156 (2001) ("[C]ollusion and inadequate representation are rampant in class actions ...."); Bruce L. Hay \& David Rosenberg, "Sweetheart" and "Blackmail" Settlements in Class Actions: Reality and Remedy, 75 NOTRE DAME L. REV. 1377, 1389 (2000) (explaining that many "[c]lass actions ... provide fertile ground for collusion, according to critics"); Samuel Issacharoff, Class Action Conflicts, 30 U.C. DAVIS L. REv. 805, 821 (1997) ("[T]he limited fund class action provides tremendous strategic incentives for collusion."); see also Deposit Guar. Nat'l Bank v. Roper, 445 U.S. 326, 339 (1980) ("That there is a potential for misuse of the class-action mechanism is obvious.").

13. See FED. R. CIV. P. $23 \mathrm{cmt}$. e (2003) ("Subdivision (e) is amended to strengthen the process of reviewing proposed class-action settlements. ... [C]ourt review and approval are essential to assure adequate representation of class members who have not participated in shaping the settlement."); Edward Brunet, Class Action Objectors: Extortionist Free Riders or Fairness Guarantors, 2003 U. CHI. LEGAL F. 403, 472 (2003) ("The proposed amendments to Rule 23 are designed to strengthen the problematic process of settlement review.").

14. Deborah R. Hensler et al., Class action Dilemmas: Pursuing Public Goals for PRIVATE GaIN $485(2000)$ (" $[I] t$ is judges who hold the key to improving the balance of good and ill consequences of damage class actions."); James D. Cox, Making Securities Fraud Class Actions Virtuous, 39 ARIZ. L. REV. 497, 524 (1997) ("Simply stated, the courts must not only become more active in their reviews but also must make the overall process more transparent."); Eisenberg \& Miller, supra note 7 , at 39 ("[O]ur study suggests that courts should be especially vigilant to police the adequacy of counsel in class cases ...."); Nagareda, supra note 5, at 168 (noting that among "the developments in class action law over the past decade" are "heightened demands for judicial scrutiny of class settlements"); see also Lisa L. Casey, Reforming Securities Class Actions from the Bench: Judging Fiduciaries and Fiduciary Judging, 2003 BYU L. REV. 1239, 1245 (2003) ("Noting that presiding judges are the self-proclaimed 'fiduciaries,' 'agents,' or 'guardians' of absent class members, scholars have proposed various mechanisms by which district judges may fulfill their duties to scrutinize (and cut) the lawyers' fee requests.").

15. FED. R. CIV. P. 23(e); see also David R. Clay, Federal Attraction for the Interstate Class Action: The Effect of Devlin v. Scardelletti and the Amendments to Federal Rule of Civil Procedure 23(e) on Class Action “Minimal Diversity” Concerns, 52 EMORY L.J. 1877, 1880 (2003).

16. Coffee, supra note 8, at 438 ("Although many reforms are possible and could succeed, only one is sure to fail: reliance on trial court scrutiny of the settlement."); Issacharoff, supra note 12, at 829 ("No matter how virtuous the judge, the fact remains that courts are overworked, they have limited access to quality information, and they have an overwhelming incentive to clear their docket. They cannot reliably police the day-to-day interests of absent class members."). 
usually complicated and lengthy - just the type of suit that judges prefer to avoid. ${ }^{17}$ For this reason, there is little hope that judicial oversight will cure the problem. ${ }^{18}$

There is, however, a way to end collusion in class settlements. Under the current system, a settlement includes every class member except those who opt out; all who remain silent are in. ${ }^{19}$ This approach differs from the way we treat other settlements and contracts, which bind only those who expressly consent. ${ }^{20}$ Such express consent is required in the nonclass context so that people will not unwittingly become bound by an agreement they would not have chosen - the very fate that now befalls class members. ${ }^{21}$ Class members should therefore be protected in the same manner as everyone else: by including in a class settlement only the people who expressly consent to its terms by opting in.

The consequences of this proposed change would be substantial. Because few people reply to the letter that notifies them of a class settlement, the opt-in rule would drastically reduce the number of class members in any settlement. ${ }^{22}$ As a result, settling a class action would no longer appeal to either a plaintiffs' lawyer or a defendant. The plaintiffs' lawyer, who receives a percentage of the total sum paid to the class members, would get a piece of a very small pie. The defendant, which seeks to preclude all class members from suing in the future, ${ }^{23}$ would be able to bind only those few who opt in.

17. See Coffee, supra note 8 , at 389 ("[O]nce a potential settlement of complex litigation is in view, federal trial courts tend to tolerate almost any conflict in order to achieve a settlement that brings litigation peace-but at a cost paid by the class members.").

18. Id. at 438 ; see Issacharoff, supra note 12 , at 829 .

19. See, e.g., Samuel Issacharoff, Governance and Legitimacy in the Law of Class Actions, 1999 SUP. CT. REV. 337, 370 (1999).

20. See Whittier Union High Sch. Dist. v. Super. Ct., 66 Cal. App. 3d 504, 508 (1977) ("The rule is almost universal that ... [w]ithout his client's free and intelligent consent, after full knowledge of all the facts and circumstances, an attorney may not surrender any substantial right of his client; nor may he impair, compromise, or destroy his client's cause of action."); Robert G. Bone, Statistical Adjudication: Rights, Justice, and Utility in a World of Process Scarcity, 46 VAND. L. REV. 561,575 (1993) ("Settlement always requires consent. Parties bargain when they settle, and all must agree to the ultimate resolution."); see also Janneh v. GAF Corp., 887 F.2d 432, 436 (2d Cir. 1989) ("A settlement is a contract, and once entered into is binding and conclusive."); Geoffrey C. Hazard, Jr., The Settlement Black Box, 75 B.U. L. REV. 1257, 1266 (1995) ("A settlement is a contract negotiated under unusually constrained conditions.").

21. See Restatement (SECOND) OF CONTRACTS § 17(1) (1981); Rhonda Wasserman, Dueling Class Actions, 80 B.U. L. REV. 461, 501-04 (2000).

22. Edward H. Cooper, The (Cloudy) Future of Class Actions, 40 ARIZ. L. REV. 923, 936 (1998) ("Inertia, the complexity of class notices, and the widespread fear of any entanglement with legal proceedings will lead many reluctant class members to forgo the opportunity to opt out, and likewise will deter many willing class members from seizing the opportunity to opt in."); see also Eisenberg \& Miller, supra note 7, at 38 ("The overwhelming inaction displayed by class members in the reported cases suggests that a class member's failure to opt-out should not readily be equated to an affirmative consent to jurisdiction. Common sense indicates that apathy, not decision, is the basis for inaction." (emphasis added)).

23. See Nagareda, supra note 5, at 163 ("Defendants want any class settlement to mark the achievement of an enduring peace in the litigation, not just a flimsy peace in our time."). 
To get what they want, the plaintiffs' lawyer and the defendant would need to litigate the case fully and receive an adjudication on the merits by a judge or a jury. Such an adjudication would bind all class members, not merely the ones who opt in. If the plaintiffs were to win, then their lawyer would receive a percentage of the award given to the entire class - a piece of a very large pie. Win or lose, the defendant would never again face litigation of the issue from any class member, because all would be bound by the judgment.

An opt-in system would not unduly discourage plaintiffs from bringing class actions; it would discourage them only from settling class actions. A class action with valid claims could still go to adjudication, where the defendant would be held accountable and the class members and their lawyer would reap the rewards they are due. The enormous payout of favorable judgments would make it worthwhile for wealthy plaintiffs' law firms to bear the costs of investigating and litigating the class actions that offer a chance of victory.

But unlike the current system, ${ }^{24}$ an opt-in system would discourage plaintiffs from bringing frivolous class actions. A lawyer who can make money only by winning at trial, not by settling before trial, will pursue only the cases that give her a viable chance to win.

Because adjudication costs more than settlement, this proposed optin system would increase the expense (to courts and parties) of meritorious class actions. However, the social benefits derived from ending collusion, and the costs saved by deterring frivolous lawsuits, are likely to outweigh the cost of funneling the remaining class actions away from settlement and into adjudication..$^{25}$

Since the inception of class litigation, our system has operated under the unstated and undiscussed assumption that the binding force of a class action settlement on absent class members must parallel that of a class action adjudication. Questioning this assumption offers fresh prospects for combating the problem of collusion in class settlements.

\section{Class AdJudications: A GoOd Opt-OUT Rule}

The adjudication of a class action binds every class member except the few who opt out. This rule is necessary to sustain class actions and thereby to safeguard the important social benefits yielded by those lawsuits.

24. Project, Developments in the Law-The Paths of Civil Litigation, 113 HARV. L. REV. 1752, 1812 (2000) [hereinafter Developments] ("Unfortunately the pressure to settle exists even with respect to frivolous filings, which are an ongoing concern in the class action context, and are as costly to litigate as legitimate claims. The pressure on defendants to settle even non-meritorious claims gives plaintiffs substantial leverage-so much so that some courts and commentators characterize it as "blackmail."”).

25. See infra Part III. 
When a corporation or an individual breaks the law in a way that harms many people, one of those people may bring suit on behalf of the others. ${ }^{26}$ The rule that authorizes such lawsuits, Rule 23 of the Federal Rules of Civil Procedure, divides class actions into three categories. ${ }^{27}$ The first category-23(b)(1)-covers cases where separate individual lawsuits might lead to unfair results for either the class members or the party opposing the class. ${ }^{28}$ The second category-23(b)(2)-involves lawsuits for injunctions rather than damages. ${ }^{29}$ The third category$23(\mathrm{~b})(3)-$ is a catchall that covers all other class actions. ${ }^{30}$

In a class action brought under either (b)(1) or (b)(2), the court need not require the parties to notify the absent class members of the lawsuit at all. ${ }^{31}$ Even if the class members learn of the action, they have no right to exclude themselves from it. ${ }^{32}$ When a court authorizes a class action under (b)(3), it must order the named plaintiff ${ }^{33}$ to send a letter to "all class members who can be identified with reasonable effort," to notify them of the lawsuit. ${ }^{34}$ Anyone who wants to be excluded from the lawsuit should tell the court at that time, although the court might grant another opportunity for exclusion later in the litigation. ${ }^{35}$

Aside from those who opt out of (b)(3) lawsuits, all class members are bound by the outcome of any class action, even if they never knew of the case. This rule is double-edged. It cuts against the usual emphasis on giving every person her day in court and, in doing so, it threatens perhaps the most central tenet of the civil justice system - that a court will not de-

26. FED. R. CTV. P. 23(a) ("One or more members of a class may sue or be sued as representative parties on behalf of all only if (1) the class is so numerous that joinder of all members is impracticable, (2) there are questions of law or fact common to the class, (3) the claims or defenses of the representative parties are typical of the claims or defenses of the class, and (4) the representative parties will fairly and adequately protect the interests of the class.").

27. For a critical discussion of these categories, see John Bronsteen \& Owen Fiss, The Class Action Rule, 78 NOTRE DAME L. REV. 1419, 1423-34 (2003).

28. FED. R. CIV. P. 23(b)(1) ("An action may be maintained as a class action if ... the prosecution of separate actions ... would create a risk of (A) inconsistent or varying adjudications with respect to individual members of the class which would establish incompatible standards of conduct for the party opposing the class, or (B) adjudications with respect to individual members of the class which would as a practical matter be dispositive of the interests of the other members not parties to the adjudications or substantially impair or impede their ability to protect their interests.").

29. FED. R. CIV. P. 23(b) ("An action may be maintained as a class action if ... the party opposing the class has acted or refused to act on grounds generally applicable to the class,.thereby making appropriate final injunctive relief or corresponding declaratory relief with respect to the class as a whole.").

30. FED. R. CIV. P. 23(b)(3) ("An action may be maintained as a class action if ... the court finds that the questions of law or fact common to the members of the class predominate over any questions affecting only individual members, and that a class action is superior to other available methods for the fair and efficient adjudication of the controversy.").

31. See FED. R. CIV. P. 23(c)(2).

32. See FED. R. CIV. P. 23(c)(2)(A)-(B).

33. Although Rule 23 permits the notice letters to be assigned to anyone, they are almost always assigned to the named plaintiff. See Eisen v. Carlisle \& Jacquelin, 417 U.S. 156, 179 (1974) ("[T]he plaintiff must pay for the cost of notice as part of the ordinary burden of financing his own suit.").

34. Id. at 174.

35. See FED. R. Civ. P. 23(c)(2)(A), (e)(3). 
cide a person's dispute without giving her a chance to tell her side of the story. ${ }^{36}$

But there is a very good reason to take this approach, even in the face of such an important countervailing value. The current default rule-i.e., a class member is a party to the lawsuit unless she opts outallows the class action to serve its central purpose of remedying and deterring dispersed harm. ${ }^{37}$ If a class action adjudication bound only the people who opted in by replying to the notice letter, then class litigation would disappear. Because people simply do not reply to notice letters, ${ }^{38}$ a lawsuit that includes only the few who reply would be too small to attract a lawyer for the group.

Eliminating the incentive to bring class actions would create a social cost that is too high to bear. If, for example, a corporation commits a tort that cheats one million people each out of ten dollars, then only a class action enables the victims to seek recompense and forces the wrongdoer to relinquish its ill-gotten profit. ${ }^{39}$ No individual can sue, because the cost of hiring a lawyer exceeds the damages owed. ${ }^{40}$ The class action thus opens an avenue to pursue compensation and deterrence that would otherwise be closed. ${ }^{41}$ When the main importance of a tort is its aggregate effect, it makes sense for a lawsuit to treat the offense accordingly - for the victimized parties to bring their action as a group. ${ }^{42}$

It is therefore essential to retain the current opt-out system for class adjudications.

36. See SteVen C. Yeazell, From Medieval Group Litigation to the Modern Class ACTION 2, 8 (1987).

37. See Lahav, supra note 11 , at 70.

38. Cooper, supra note 22, at 936; Eisenberg \& Miller, supra note 7, at 40; Benjamin Kaplan, Continuing Work of the Civil Committee: 1966 Amendments of the Federal Rules of Civil Procedure (I), 81 HARV. L. REV. 356, 397-98 (1967) (“[R]equiring the individuals affirmatively to request inclusion in the lawsuit would result in freezing out the claims of people-especially small claims held by small people - who for one reason or another, ignorance, timidity, unfamiliarity with business or legal matters, will simply not take the affirmative step.").

39. See Hay \& Rosenberg, supra note 12, at 1380 ("The potential virtue of a class action is that it prevents the defendant from using the plaintiffs' numerosity against them. Once the plaintiffs' claims are aggregated and the task of representing them assigned to a single group of attorneys, the plaintiffs can exploit the same scale economies as the defendant when investing in the case.").

40. See Lahav, supra note 11, at 70 ("Among other things, class actions solve the collective action problems faced by individuals with claims too small to be economically adjudicated individually, and address certain small private wrongs with substantial public effects, especially in the absence of governmental intervention."); Developments in the Law-Toxic Waste Litigation, 99 HARV. L. REV. 1458, 1467 (1986) ("Because each victim's share of the aggregate harm is small relative to the costs of litigation, no single victim finds pursuit of either damages or injunctive relief a worthwhile investment.").

41. See Lahav, supra note 11 , at 70.

42. See Hay \& Rosenberg, supra note 12 , at $1380 \mathrm{n} .10$ ("The policy at the very core of the class action mechanism is to overcome the problem that small recoveries do not provide the incentive for any individual to bring a solo action prosecuting his or her rights. A class action solves this problem by aggregating the relatively paltry potential recoveries into something worth someone's (usually an attorney's) labor."). 


\section{Class SETTLEMENTS: A BROKEN SYSTEM}

Few class actions actually go to adjudication; nearly all of them settle. Unlike adjudication, settlement enables plaintiffs' lawyers and defendants to craft the outcome of a case. How they craft that outcome is influenced heavily by the current opt-out rule, which lets them enrich themselves at the expense of the class members. The current rule relies upon judges and absent class members to thwart such collusion, but those people have strong incentives to abdicate their policing duties. As a result, collusion undercuts the social value of class litigation.

\section{A. Collusion}

Our current approach to class settlements enables plaintiffs' attorneys to collude with defendants in crafting settlements that pay the absent class members less than the expected value of the litigation. ${ }^{43}$ Such collusion harms society even when each class member's claim is small, because it prevents the civil justice system from properly deterring defendants from breaking the law for profit ${ }^{44}$ It is a widespread and intractable problem. ${ }^{45}$

When a class action under Rule $23(b)(1)$ or (b)(2) settles, "[t]he court must direct notice in a reasonable manner to all class members who would be bound by a proposed settlement." ${ }^{46}$ But if a class member receives such a notice and tells the court that she wants no part of the agreement, the court can deny her opt-out request. ${ }^{47}$ Class members have the right to opt out of lawsuits brought under 23(b)(3), but that right is guaranteed only at the initial stage of the lawsuit. If the case later settles, then the settlement may bind all those who did not opt out originally, even though the class members could not have known the terms of the settlement at the time they were given their chance to opt out. ${ }^{48} \mathrm{~A}$ court is permitted, but not required, to insist that the parties offer absent class members a new opportunity to opt out once the terms of the settlement have been crafted. ${ }^{49}$ Any class members who could not originally

43. Issacharoff, supra note 12, at 821 ("In fact, there is no better formula for collusion than a situation in which the rights of non-participants can be extinguished without notice or an opportunity to get out from under a prospective court decree.").

44. See Lahav, supra note 11 , at 71 ("It may be that the smaller the likely compensation to the individual, the more important the deterrence justification becomes."); David L. Shapiro, Class Actions: The Class as Party and Client, 73 NOTRE DAME L. REV. 913, 923-31 (1998).

45. See, e.g., Coffee, supra note 10, at 677 ("Ultimately, the most persuasive account of why class actions frequently produce unsatisfactory results is the hypothesis that such actions are uniquely vulnerable to collusive settlements that benefit plaintiff's attorneys rather than their clients."); Koniak \& Cohen, supra note 12 , at 156 ("[C]ollusion and inadequate representation are rampant in class actions ....").

46. FED. R. CIV. P. 23(e)(1)(B).

47. E.g., Mollie A. Murphy, The Intersystem Class Settlement: Of Comity, Consent, and Collusion, 47 U. KAN. L. REV. 413, 452-53 (1999).

48. FED. R. CIV. P. 23(e)(3).

49. Id. 
be identified "through reasonable effort" are bound by the settlement even if they never were sent any notice of the class action. ${ }^{50}$ The same is true of class members who were sent, but who never received, notice letters.

Class members thus play virtually no role in their own lawsuit. ${ }^{51}$ Instead, class litigation is driven by the two entities with the most at stake: the plaintiffs' lawyer and the defendant. The former pursues a potentially costly and time-consuming lawsuit in the hope that the suit will yield a vast profit. ${ }^{52}$ The latter faces the danger of a huge loss, but also the prospect of freeing itself from all future risks posed by the claims being raised. ${ }^{53}$ Each player seeks to make as much or lose as little money as possible, while incurring the lowest risks and transaction costs.

A settlement is ideal for reducing risks and costs. Both sides avoid the expense of trial, the defendant avoids the danger of a devastating award of damages by a judge or a jury, and the plaintiffs' lawyer avoids the danger of wasting considerable time and money on a case that she ultimately might lose and for which she would then be paid nothing at all. Despite these mutual benefits of settlement, it might seem that the plaintiffs' lawyer and the defendant remain adversaries because the former wants the settlement to be large whereas the latter wants it to be small. The plaintiffs' lawyer's fee is typically a percentage of the money that the class recovers from the lawsuit. ${ }^{54}$ It would appear, therefore, that absent class members could trust their lawyer to press for as large a settlement award as possible.

But this is not so, for many reasons. One is that litigating a case saddles the lawyer, but not the class members, with opportunity costs. The lawyer could settle many cases in the time it takes to litigate one, so it is rational for her to settle quickly even if doing so reduces her profit in

50. See Marcus, supra note 9, at 892 ("In the Agent Orange litigation, the Second Circuit found that preclusion applied to claimants with after-arising claims even though they did not receive notice, emphasizing the adequacy of representation these claimants received from others.").

51. E.g., Eisenberg \& Miller, supra note 7, at 5 ("This evidence supports the claim, often found in the literature, that class counsel controls the litigation.").

52. Jonathan R. Macey \& Geoffrey P. Miller, The Plaintiff's Attorney's Role in Class Action and Derivative Litigation: Economic Analysis and Recommendations for Reform, $58 \mathrm{U}$. CHI. L. REV. 1, 3 (1991) (“Accordingly, plaintiffs' class and derivative attorneys function essentially as entrepreneurs who bear a substantial amount of the litigation risk and exercise nearly plenary control over all important decisions in the lawsuit."); see also Nagareda, supra note 5, at 164 ("For class actions, no less than for any economic market, monopoly power carries the usual potential for higher prices and lower output. Here, higher prices come in the form of excessive fees for class counsel, and lower output consists of low-quality representation of the class in the form of an inadequate settlement.").

53. See Nagareda, supra note 5, at 164 ("The monopoly is what enables class counsel to tender for sale the entirety of claims in the litigation and, hence, the prospect of lasting peace for the defendant.").

54. E.g., Issacharoff, supra note 12, at 829 . A less common fee arrangement, the "lodestar" method, is based on the number of hours the lawyer works on the case. This method has fallen into disfavor because it fails even more strikingly than does the contingent fee to tie the lawyer's fate to that of the class. As a result, it results in collusion even more than does the contingent fee. For a discussion of the many drawbacks of the lodestar method, see Charles Silver, Class ActionsRepresentative Proceedings, in 5 ENCYCLOPEDIA OF LAW AND ECONOMICS 194, 211-13 (2000). 
the individual case. This calculation redounds to the detriment of class members, who receive less than the amount that would be their expected value from a trial or from a negotiation conducted with only their interests in mind. ${ }^{55}$

Another factor that causes the interests of plaintiffs' lawyers to diverge from those of their clients is the discrepancy between the attorney's fee (which is large) and each class member's recovery (which is far smaller). Because of the declining marginal value of money, ${ }^{56}$ accepting an early settlement to avoid the costs and risks of trial makes far more sense for the lawyer than it does for the class members. ${ }^{57}$ A class member with typical risk preferences would prefer a $75 \%$ chance of receiving $\$ 100$ to a certainty of receiving $\$ 25$. But a plaintiffs' lawyer with the same typical risk preferences would prefer a certainty of receiving $\$ 5$ million to a $75 \%$ chance of receiving $\$ 20$ million, because the first $\$ 5$ million means far more to most people than does the next $\$ 15$ million..$^{58}$ This problem would be less severe if the lawyer or her firm had assets that dwarf the settlement fee, because such a firm might be risk-neutral with respect to $\$ 5$ million, just as a class member is risk-neutral with respect to $\$ 25$. But not all plaintiffs' lawyers have vast resources, or a large and diverse pool of class lawsuits to pursue. And for those who are fortunate enough to have those things, the opportunity costs discussed above loom particularly large.

In any event, the client rather than the lawyer is most trustworthy in making the choice to accept a settlement offer, ${ }^{59}$ but in a class action settlement, the lawyer strikes the deal without getting approval from most of the clients. The named plaintiffs typically look the other way because, even when they are not paid off with "bonuses" for their willingness to represent the class, ${ }^{60}$ their recoveries are often too small to be worth the trouble; and if they objected, the court might approve the settlement nonetheless. ${ }^{61}$

55. Silver, supra note 54, at 213. Of course, the expected value to which I refer incorporates (i.e., is discounted in accordance with) the possibility that the plaintiffs will lose at trial, or that they will win only a small amount. Even with such discounting, class actions are typically worth more to the class members than the settlement gives them. Id.

56. Id. at 214 .

57. Coffee, supra note 8, at 391 ("Across a broad range of cases, plaintiffs' attorneys will be more risk averse than class members in considering settlement offers and will wish to accept many offers that the class will rationally wish to reject."); Silver, supra note 54, at 213.

58. See Recent Case, 116 HARV. L. REV. 2702, 2707 (2003) (noting that in class actions, "contingent fees encourage lawyers to avoid trial expenses by settling early for an amount that does not generally maximize net claim value").

59. Issacharoff, supra note 12, at $811 \mathrm{n} .17$ ("[S]ettlement decisions ultimately reflect an assessment of risk and are subject to individual variations in risk-seeking or risk-aversion-decisions which should presumptively be left to the affected individuals."); see also MODEL RULES OF PROF'L CONDUCT R. 1.8(g) (2002).

60. See Clinton A. Krislov, Scrutiny of the Bounty: Incentive Awards For Plaintiffs In Class Litigation, 78 ILL. B.J. 286, 286-87 (1990).

61. Parker v. Anderson, 667 F.2d 1204, 1211 (5th Cir. 1982). 
Plaintiffs' lawyers and defendants also harm absent class members by circumventing the contractual link between the lawyer's fee and the sum that the class actually receives. Like any other contract, a settlement can have whatever terms the parties desire. ${ }^{62}$ Class members can therefore receive payment in a form other than cash in return for their agreement to waive their right to pursue present and future litigation. A classic example of such alternative payment is coupons. ${ }^{63}$ A settlement might require the defendant to give each class member a coupon for the reduction in cost of a product sold by the defendant. ${ }^{64}$ The plaintiffs' lawyer receives a percentage of the total value, as measured by criteria listed in the settlement agreement, of all the coupons given to the class. By overstating that value, plaintiffs' attorneys can receive a higher fee relative to the class's recovery than they deserve under the fee arrangement. ${ }^{65} \mathrm{~A}$ plaintiffs' lawyer can thus collude with a defendant to structure a deal that gives the class members coupons worth far less than the class's expected recovery, but that values the coupons at more than the expected

62. Of course, it must not violate public policy or be void on any other contractual ground. But the law of contracts makes clear that voiding a contract over the objections of both parties is exceptional. See, e.g., Baltimore \& Ohio S.W.R. Co. v. Voight, 176 U.S. 498, 505 (1900) ("[T]he right of private contract is no small part of the liberty of the citizen, and ... the usual and most important function of courts of justice is rather to maintain and enforce contracts, than to enable parties thereto to escape from their obligation on the pretext of public policy, unless it clearly appear that they contravene public right or the public welfare."); Gates Corp. v. Bando Chem. Indus., 4 F. App'x 676, 686 (10th Cir. 2001) ("Parties to a contract ... may agree on whatever terms they see fit so long as such terms do not violate statutory prohibitions or public policy." (internal quotation marks omitted)); Peoples Bank \& Trust Co. v. Price, 714 N.E.2d 712, 716 (Ind. Ct. App. 1999) ("[A]s a general rule, the law allows competent adults the utmost liberty in entering into contracts .... Nevertheless, despite the very strong presumption of enforceability, courts have refused to enforce private agreements that contravene statute, clearly tend to injure the public in some way, or are otherwise contrary to the declared public policy ....); 15 Grace McLane Giesel, Corbin ON Contracts \$ 79.4 (Joseph M. Perillo ed., rev. ed. 2003) ("[C]ourts of today seem reticent to refuse to enforce contracts unless the public policy of the jurisdiction is fairly clear."); Steven W. Feldman \& James A. DeLanis, Resolving Contractual Ambiguity in Tennessee: A Systematic Approach, 68 TENN. L. REv. 73, 76 n.9 (2000) ("The cases partially address such objections, upholding contracts in doubtful cases and requiring a welldefined, dominant public policy, where public detriment will probably result before the contract is deemed void."); $c f$. Baravati v. Josephthal, Lyon \& Ross Inc., 28 F.3d 704, 709 (7th Cir. 1994) ("Indeed, short of authorizing trial by battle or ordeal or, more doubtfully, by a panel of three monkeys, parties can stipulate to whatever procedures they want to govern the arbitration of their disputes; parties are as free to specify idiosyncratic terms of arbitration as they are to specify any other terms in their contract.").

63. Geoffrey Miller \& Lori Singer, Nonpecuniary Class Action Settlements, 60 LAW \& CONTEMP. PROBS. 97, 102 (1997).

64. See Christopher R. Leslie, A Market-Based Approach to Coupon Settlements in Antitrust and Consumer Class Action Litigation, 49 UCLA L. REv. 991, 995 ("Coupons have also provided the essential currency to settle a vast variety of consumer class actions.").

65. See infra note 92 and accompanying text. Stopping attorneys from overstating the value of coupons is more difficult than it might seem. See infra text accompanying notes 92-101. 
recovery. ${ }^{66}$ The result would be a windfall to the defendant and to the plaintiffs' lawyer, at the expense of absent class members. ${ }^{67}$

Another form of collusion in class settlements is "reversion." This occurs when the plaintiffs' lawyer and the defendant craft a settlement that calls for the defendant to place money in a fund for class members. Each class member may claim the small amount to which she is entitled, but all unclaimed funds revert to the defendant. The plaintiffs' lawyer receives a percentage of the overall amount paid into the fund, but both that lawyer and the defendant know the class will ultimately receive far less than this overall amount because "claim rates in class actions tend to be low." ${ }^{68}$ Thus the defendant pays less than it should, ${ }^{69}$ the plaintiffs' lawyer makes more than he should, ${ }^{70}$ and the class members lose out (as do victims of the future misconduct that goes underdeterred).$^{71}$

All of these problems are aggravated by a powerful trump card often held by a class action defendant. If the lawyer for a plaintiff class refuses to settle a case on terms favorable to the defendant, then the defendant can seek out another lawyer and encourage him to bring a separate but identical class action and settle it on the proposed terms. ${ }^{72}$ Because "the first class action to settle moots all other similar class actions and ... only the attorney handling the settled case is likely to earn a fee," ${ }^{73}$ such a deal would give a windfall to the new lawyer and the defendant while leaving the original lawyer empty-handed. To avoid this fate, plaintiffs' lawyers face pressure to settle on terms that favor the defendant - and themselves - but not the absent class members or the civil justice system. $^{74}$

66. See Leslie, supra note 64 , at 996 ("Although the class counsel is supposed to represent the class's interests and be compensated based on how well it does so, coupon settlements decouple the interests of the class and its counsel.").

67. Id. at 995 ("While this represents a win-win scenario for the class counsel and the defendant, many class members are left uncompensated.").

68. Silver, supra note 54 , at 214.

69. That is, it pays less than it would have expected to pay if it had either gone to adjudication or engaged in fair, fully adversarial settlement negotiations.

70. That is, he receives a higher percentage of the class's actual recovery than he would have received if the class members had ended up with the full sum of money upon which the lawyer's contingent fee was calculated.

71. See Silver, supra note 54 , at $213-14$.

72. Coffee, supra note 8, at 393 (“[R]ational plaintiffs' attorneys will need to consider ... the prospect that a competitor may emerge, thereby inclining them to accept a cheaper settlement."); Silver, supra note 54, at 214-15; see also John C. Coffee, Class Wars: The Dilemma of the Mass Tor Class Action, 95 CoLUM. L. REV. 1343, 1365 (1995).

73. Silver, supra note 54, at 214.

74. Id. at 214-15; see also Coffee, supra note 72, at 1371-72. 


\section{B. Policing Collusion Within the Opt-Out System}

Rule 23 seems to protect absent class members against collusion by requiring that any settlement be approved by the court. ${ }^{75}$ Indeed, a principal aim of the 2003 amendments to the rule was to strengthen judicial oversight of class settlements. ${ }^{76}$ These amendments respond to the calls of many commentators for such scrutiny as a means of curing the problem of collusion. ${ }^{77}$

But judicial oversight faces substantial obstacles. First, it is not at all clear that judges want to stop collusive settlements. ${ }^{78}$ Whenever a judge rejects such a deal, she risks forcing the parties to litigate the case fully, thereby increasing her own workload. A federal district court judge recently explained that he opposes reforms aimed at thwarting collusive coupon settlements because "[f]rom the court's perspective, it would be terrible if a case went to trial because a settlement option is not available."79 Due to the "overwhelming incentive to clear their docket," ${ }^{80}$ judges are "subjected to strong institutional pressures to move cases along." 81 To say the least, they "lack appropriate incentives" 82 to police the settlements. ${ }^{83}$ When courts turn a blind eye to "suspicious signs of collusion[,] . . . the fact of judicial self-interest must be placed at center stage." 84

Review by appellate judges also offers little hope. Faced with crowded dockets of their own, they are sensitive to the workload concerns of the trial court judges, who are often their friends. Moreover, they are even less capable than are trial judges of investigating the fair-

75. FED. R. CIV. P. 23(e)(1)(A) ("The court must approve any settlement, voluntary dismissal, or compromise of the claims, issues, or defenses of a certified class.").

76. FED. R. CIV. P. 23(e) advisory committee's note ("Subdivision (e) is amended to strengthen the process of reviewing proposed class-action settlements. Settlement may be a desirable means of resolving a class action. But court review and approval are essential to assure adequate representation of class members who have not participated in shaping the settlement.").

77. See, e.g., Marcus, supra note 9, at 907; Judith Resnik, Litigating and Settling Class Actions: The Prerequisites of Entry and Exit, 30 U.C. DAVIS L. REV. 835, 858 (1997); Georgene M. Vairo, The Dalkon Shield Claimants Trust, and the Rhetoric of Mass Tort Claims Resolution, 31 LOY. L.A. L. REV. 79, 161-62 (1997); Brian Wolfman \& Alan B. Morrison, Representing the Unrepresented in Class Actions Seeking Monetary Relief, 71 N.Y.U. L. REV. 439, 477-501 (1996).

78. Coffee, Class Wars, supra note 72 , at 1462 ; Issacharoff, supra note 12, at 829; Silver, supra note 54 , at 216 .

79. Class Action Lawyers Doubt Provisions in Legislation Aimed at Curbing Abuses, 72 U.S.L.W. (BNA) 2593 (Apr. 6, 2004) (quoting Judge Frederick Motz of the District of Maryland), available at http://pubs.bna.com/ip/BNA/law2.nsf/is/a0a8h2k7f7.

80. Issacharoff, supra note 12, at 829; see also James A. Henderson, Jr., Settlement Class Actions and the Limits of Adjudication, 80 CORNELL L. REV. 1014, 1021 (1995) ("The court has a direct and personal benefit to be gained by approving the settlement ....").

81. Silver, supra note 54, at 216; see also Coffee, supra note 72 , at 1462 ("[T] courts in handling mass tort class actions appears to have varied in direct proportion to the amount of docket pressure under which the trial court has perceived itself to be.").

82. Silver, supra note $\$ 4$, at 216.

83. Possibly adding to the problem is the fact that, according to many, judges are "overworked." Issacharoff, supra note 12, at 829; see also Silver, supra note 54, at 216.

84. Coffee, supra note 72 , at $1462-63$. 
ness of a settlement in the absence of meaningful adversarial proceedings. They are therefore loath to reject a settlement approved by a lower court: "Our appellate review of the district court's approval of a settlement is limited; an approved settlement will not be upset unless the court clearly abused its discretion.... [O]ur limited review rule is a product of the strong judicial policy favoring the resolution of disputes through settlement." 85

Second, even the most willing judge might well be unable to determine that a settlement is unfair to absent class members. The "job of policing substantively defective settlements" is "almost impossible" cause a court cannot gauge what sort of deal would have been struck under truly adversarial conditions. There is no "market" for class settlements, ${ }^{87}$ and the most comparable cases are usually other class actions that were settled collusively. ${ }^{88}$ Moreover, every settlement is simply a contract and as such depends upon the risk preferences of the parties. ${ }^{89}$ It is impossible to know - with the level of confidence a court would want to have-that most class members would prefer to risk rejecting an early settlement offer, even though their lawyer would prefer to accept it, due to the opportunity cost of litigation or to money's declining marginal value. There is thus a "lack of objective fairness criteria in class action settlements." ${ }^{90}$

Even the most egregious tactics can be difficult to stop. In coupon settlements, plaintiffs' lawyers hire experts to assess the value of the coupons, and those experts typically base their assessments on "wildly optimistic" assumptions about the number of class members likely to use the coupons. ${ }^{91}$ How can judges establish that the assessments are unreasonable? Judges have "limited fact-gathering capabilities" 92 and "limited access to quality information." They "have to rely on others for most of their information. Yet their usual sources-class counsel and defen-

85. Parker v. Anderson, 667 F.2d 1204, 1209 (5th Cir. 1982); see also Mendoza v. United States, 623 F.2d 1338, 1344 (9th Cir. 1980), cert. denied, 450 U.S. 912 (1981) ("Broad discretion is granted to the trial judge, enabling him or her to respond fluidly to the varying needs of particular cases. Therefore, although certain factors must be considered and certain procedures complied with, much of the judicial oversight of class actions is in the form of the sound discretion of the District Court.").

86. Issacharoff, supra note 12 , at 830 .

87. Hazard, supra note 20 , at 1266 ("Moreover, there is no shared reference point as to the value of the claim, such as 'reasonable market price.' Litigation claims have no market in the understood sense of that term.").

88. Silver, supra note 54, at 216.

89. Issacharoff, supra note 12 , at $811 \mathrm{n} .17$.

90. Id. at 830 n.79 (citing Geoffrey C. Hazard, Jr., The Settlement Black Box, 75 B.U. L. REV. $1257,1266-68(1995))$.

91. Silver, supra note 54, at 213; accord Severin Borenstein, Settling for Coupons: Discount Contracts as Compensation and Punishment in Antitrust Lawsuits, 39 J.L. \& ECON. 379, 380-81 (1996).

92. Silver, supra note 54 , at 216.

93. Issacharoff, supra note 12 , at 829. 
dants-cannot be relied upon to pinpoint evidence that would scuttle a deal." 994

Filling this adversarial void has proven most difficult. Even if some individual members of the class - be they named plaintiffs or absent class members - know of the deal and realize that it is unfair, they are unlikely to stop the settlement. ${ }^{95}$ In most class actions, the cost of hiring experts ${ }^{96}$ or of otherwise mounting an effective case exceeds a class member's expected recovery. ${ }^{97}$ And even a truly vigilant class member might be "bought off" by the defendant and the plaintiffs' lawyer, who can make the disgruntled individual a named plaintiff and accordingly give him the bonus ${ }^{98}$ those plaintiffs may receive. ${ }^{99}$ Under these circumstances, it is no wonder that "[j]udges approve settlements in ninety percent of the cases where objections are filed." 100

This is not to say that meaningful reforms are impossible within the opt-out system. Prohibiting reversion and coupon settlements would be a step in the right direction. Another good step might be to replace the rule that "the first class action to settle moots all other similar class actions" with a rule privileging the first class action to be filed. These sorts of reforms would improve upon the status quo, but they would still fall far short of the goal of ending collusion. Due to opportunity costs and risk aversion, even with these reforms lawyers would continue to settle cases for less than they would if their interests were aligned with those of their clients.

The law and economics literature has made a collection of reform proposals of a different sort, many of which involve using an auction to sell either the entire lawsuit or the mere right to be the attorney who litigates it. Rather than give a survey of that literature here, I refer readers to the very useful account of it in a recent article by Alon Harel and Alex Stein in the Yale Law \& Policy Review. ${ }^{101}$ Harel and Stein explain the problems with each proposal. One important theme running through those problems is that, due to the severe danger of overbidding, the proposed auctions would attract too few buyers who would each bid far lower than the actual value of the lawsuit. ${ }^{102}$ Such a result would create

94. Silver, supra note 54, at 216; see also Issacharoff, supra note 12, at 808 ("Perhaps in no other context do we find courts entering binding decrees with such a complete lack of access to quality information and so completely dependent on the parties who have the most to gain from favorable court action."); Leslie, supra note 64, at 996-97 ("[B]ecause actual coupon value is difficult for courts to calculate, coupon settlements afford class counsel an opportunity to convince a reviewing judge that the settlement is more valuable than it actually is, and thereby increase the attorneys' fees awarded.").

95. See Silver, supra note 54, at 215-16.

96. See, e.g., David Medine, The Constitutional Right to Expert Assistance for Indigents in Civil Cases, 41 HASTINGS L.J. 281, 291 (1990).

97. Silver, supra note 54 , at 216.

98. See Krislov, supra note 60 , at $286-87$.

99. Silver, supra note 54, at 215-16.

100. Id. at 217; see also Eisenberg \& Miller, supra note 7, at 34 .

101. Harel \& Stein, supra note 11, at 90-107.

102. Id. at $91-92$. 
the same problems of underdeterrence and undercompensation as the current system. ${ }^{103}$

\section{AN OPT-IN RULE FOR CLASS SETTLEMENTS}

If we adopted an opt-in rule for class settlements while retaining the opt-out rule for class adjudications, then we would end collusion without compromising the valuable social functions of the class action. This change would funnel class lawsuits away from settlement and into adjudication, where collusion would be more difficult to sustain. The resulting increase in the workload of a few judges is an acceptable price for deterring companies from inflicting dispersed harm and for fairly compensating the victims of such harm.

\section{A. Removing the Incentives That Lead to Collusion}

What would happen if we switched to a system in which a class settlement included only those who replied to notice letters and expressed their assent to the terms of the deal? In such an opt-in system, all class members who do not opt in would receive nothing but would retain their right to file their own lawsuits.

It is likely that only a small percentage of class members would take the trouble to opt in. ${ }^{104}$ As a result, the settlement would give neither the plaintiffs' lawyer nor the defendant what it wants. ${ }^{105}$ The plaintiffs' lawyer receives a percentage of the total sum given to the class members; if that sum included only the payouts to the few who opted in, then the lawyer's take would be very small. The defendant, who seeks to use the class action to free itself, once and for all, of liability to the class members, ${ }^{106}$ would be able to preclude only a few people from suing in the future. A settlement would thus offer no big payout to the lawyer and no peace for the defendant. These deals, currently so attractive to both of the powerful players in class litigation, would become undesirable to those players.

Some might suggest that this change would produce better notice to class members. If both the plaintiffs' lawyer and the defendant could get what they wanted only through bringing large numbers of people into the class, and if that in turn could be accomplished only by convincing many

103. Unfortunately, Harel and Stein's own auction solution fails to escape this problem.

104. E.g., HENSLER ET AL., supra note 14, at 15 \& n.22; Cooper, supra note 22, at 936 ("Inertia, the complexity of class notices, and the widespread fear of any entanglement with legal proceedings ... will deter many willing class members from seizing the opportunity to opt in."). Those who opt in would be freely choosing to enter the deal, unlike class members who do not reply to notice letters in the opt-out system.

105. See Samuel Issacharoff, supra note 19, at 370 ("[A]ny requirement that the consent of all the governed is the prerequisite to judicial approval of the maintenance or settlement of a class action threatens the viability of this aggregative tool.").

106. Id. at 345 . 
people to opt in, then notice letters might become very persuasive and easy to understand. Such an outcome would be welcome. Many have criticized notice letters for being difficult to understand, so as to discourage class members from responding. ${ }^{107}$ Making a response desirable to the senders would create an incentive for the letters to be user-friendly.

It is more likely, however, that the plaintiffs' lawyer and the defendant would take a different approach. They would realize that even the most effective notice letters are unlikely to persuade most class members to opt in. Moreover, persuading many to opt in would still be insufficient for a defendant to get what it wants-litigation peace. As long as a large number of class members remain outside the settlement, there will always be the danger of future litigation that could result in a substantial judgment. As a result, the plaintiffs' lawyer and the defendant would need to pursue their goals through a different channel.

That channel is adjudication. The opt-in regime would apply only to settlement; an adjudicated class action would still include every class member except those who opt out. ${ }^{108}$ Plaintiffs' lawyers and defendants could therefore use class adjudication to achieve the ends they currently achieve via class settlement. If the plaintiff class wins at trial, then its lawyer will reap a huge reward. Regardless of the outcome of the trial, the defendant will be free of all future litigation from any class member.

Because judgments, unlike settlements, are crafted by the court rather than by the parties and their lawyers, an opt-in system would greatly reduce the opportunity to collude. It would thus solve the main problem that currently plagues class actions.

\section{B. Is the Cure Worse Than the Disease?}

Even if an opt-in system would end collusion, would it create more problems than it solves? The most troubling possibility is that it would discourage plaintiffs' attorneys from filing class lawsuits by making the reward for such cases more difficult, time-consuming, costly, and uncertain to obtain. ${ }^{109}$ Lawyers will be less inclined to invest in class actions if their return on the investment depends on securing a favorable verdict rather than merely a lucrative settlement. This phenomenon might cause particularly severe harm in cases where each class member's claim is small and therefore could not be brought individually-the cases for which the class action is most needed.

107. E.g., Henry Paul Monaghan, Antisuit Injunctions and Preclusion Against Absent Nonresident Classmembers, 98 CoLUM. L. REV. 1148, 1185 (1998) ("Class notices are complex, all too often uninformative, and misleading. They are designed to encourage inaction; and they are frequently 'incomprehensible to average citizens." (citation omitted)).

108. Of course, in some class actions no one may opt out. Only members of a class certified under Rule 23(b)(3), not under 23(b)(1) or (b)(2), may opt out. FED. R. CIV. P. 23(c)(3).

109. See generally Halfteck, supra note 1. 
This concern is real and important. Yet the extent to which it is troubling depends in part on one's view of the investment incentives created by the current system. Many defendants and commentators argue that plaintiffs routinely file frivolous class actions because they know that defending the lawsuit costs more, and is riskier, than settling it. ${ }^{10}$ According to some, the vast majority of class actions fall into this category. ${ }^{11}$ If these critics are right, then a system that reduces incentives to file class lawsuits might be better, not worse, than the status quo.

Indeed, an opt-in system would operate mainly to discourage the least meritorious class actions. Where settlement is undesirable for all, a plaintiffs' lawyer will be able to profit only by receiving a favorable verdict. Such an outcome is unlikely if the lawsuit is frivolous, so plaintiffs' lawyers can be expected to avoid the expense of litigating such suits.

What about meritorious class actions? Ideally, the procedure governing class actions should be structured to align the private interest in pursuing such actions with the public benefit the lawsuits create. ${ }^{112} \mathrm{Be}$ cause many elements affect a lawyer's decision to invest in a class action, much empirical and conceptual work remains to be done in moving toward that alignment. ${ }^{113}$ At present, it is impossible to know the extent to which an opt-in rule would deter lawyers from filing meritorious class lawsuits. But if I were to venture a guess, I would weigh heavily the consideration that in meritorious cases, victory at adjudication brings such exorbitant payouts to the lawyer that she will have an incentive to pursue the lawsuit despite the substantial cost and uncertainty of trial. This holds most strongly for large plaintiffs' firms that have the resources to litigate many class actions in an attempt to win one. It seems likely that when the class members' claims are valid, the probability of success at adjudication will often be high enough - when combined with the enormous rewards of winning - to motivate a plaintiffs' attorney. In any event, the collusive settlements that characterize the status quo offer so little compensation and deterrence that they likely generate less social welfare than a system in which fewer meritorious lawsuits are filed but all of them go to adjudication.

110. E.g., Developments, supra note 24 , at 1812 ("Unfortunately the pressure to settle exists even with respect to frivolous filings, which are an ongoing concern in the class action context, and are as costly to litigate as legitimate claims. The pressure on defendants to settle even non-meritorious claims gives plaintiffs substantial leverage - so much so that some courts and commentators characterize it as 'blackmail.'”); Randy Kozel \& David Rosenberg, Solving the Nuisance-Value Settlement Problem: Mandatory Summary Judgment (Harvard Public Law Working Paper No. 90, 2004), available at http://ssrn.com/abstract=485242; see also, e.g., In re Rhone-Poulenc Rorer Inc., 51 F.3d 1293, 1299 (7th Cir. 1995) (noting that defendants' only choices are "to stake their companies on the outcome of a single jury trial, or be forced by fear of the risk of bankruptcy to settle even if they have no legal liability"); Henry J. Friendly, FEDERAL JuRISDICTION: A GENERAL VIEw 120 (1973); Milton Handler, The Shift from Substantive to Procedural Innovations in Antitrust Law, 71 CoLUM. L. REV. 1, 9 (1971).

111. See, e.g., Eric D. Green, What Will We Do When Adjudication Ends? We'll Settle in Bunches:

Bringing Rule 23 into the Twenty-First Century, 44 UCLA L. REV. 1773, 1775 (1997).

112. E.g., Halfteck, supra note 1, at 11 \& n.17.

113. Id. at 55-58. 
It is true that class actions that cannot be tried (e.g., because they are unmanageable) would no longer be able to settle, unless an effective opt-in mechanism could be created. This is no great cause for concern. An unmanageable class should be broken into smaller parts - perhaps by dividing the full set of plaintiffs into subgroups, each of which includes only similarly situated members - and litigated accordingly.

Another concern is that the opt-in system will clog the courts by replacing settlements with trials. Despite the expected decrease in frivolous litigation, it is true that an opt-in rule would likely place an added burden on the courts. Although it is not clear how best to measure empirically the benefits of ending collusion, in order to compare those benefits with the cost of trials, the benefits here seem likely to far outweigh the costs. Even if every class action that is currently settled would instead be litigated (a clearly false premise), the overall effect on the court system would be relatively minor because class actions comprise so tiny a fraction of all cases. ${ }^{114}$ It is true, of course, that a class action might consume far more resources than an ordinary individual case. But by certifying a class, a court has already saved the system and the parties enormous resources by using a single trial to resolve thousands or millions of disputes. Preventing further resources from being saved via settlement is, by comparison, a drop in the bucket. Ending collusion, on the other hand, is an important step toward deterring corporations from enriching themselves via the infliction of dispersed harm.

It is reasonable to fear that judges would respond to the opt-in rule by finding new ways to avoid trial. They might deny more requests for class certification, or they might grant more motions to dismiss or motions for summary judgment in class actions. These negative by-products of the opt-in system are likely to occur, at least at the margins, but they are very unlikely to be either as harmful or as prevalent as judicial approval of collusive settlements. First, it is easier for a judge to abdicate responsibility when her duty is merely to supervise a deal than when it is to render a judgment. In reviewing a settlement, the judge is asked only to demand that it be adequate, not that it be the right legal outcome. ${ }^{115}$ Accustomed to shouldering the responsibility for the outcome of a case-and accustomed to being equipped with a meaningful adversary process to help render that outcome - a judge might understandably conceive her role in settlement review as vanishingly limited. It is ultimately the parties and their agents who are responsible for a bad deal, whereas

114. Compare Samuel Issacharoff, Contractual Liberties in Discriminatory Markets, 70 TEX. L. REV. 1219, 1236 (1992) ("Take, for example, the number of class actions filed per year in the federal courts. In 1976, that number stood at 3584. A decade later it was only 736 , and it has stayed consistently under 1000 since that time."), with Gary D. Williams, Weighing the Costs and Benefits of Mediating Estate Planning Issues Before Disputes Between Family Members Arise: The Scale Tips in Favor of Mediation, 16 OHIO ST. J. ON DISP. RESOL. 819 n.3 (2001) ("Today, we ... file more lawsuits (15 million per year), than any other country in the world.").

115. See infra Part IV. 
the judge is principally to blame for a wrongful denial of class certification or a wrongful grant of a motion to dismiss. Second, judges always have the power to act in their own interests by granting motions to dismiss or motions for summary judgment, but there is less evidence of abuse of such power than there is in the context of settlement review. ${ }^{116}$ Although more attention should probably be paid to judicial self-interest in other contexts, the outcry against approved collusive settlements suggests that those settlements represent a larger and more pressing problem.

A final worry is that in an opt-in system, collusive trials would replace collusive settlements: the plaintiffs' lawyer and the defendant could secretly agree to manipulate the verdict by pulling their punches at trial. Indeed, a judge's role in a trial is less active and inquisitorial, at least in theory, than in a settlement review hearing. Nevertheless, colluding at trial is far riskier and more difficult to execute than is colluding in a settlement. In a recent article, Randy Kozel and David Rosenberg argue for discouraging frivolous class lawsuits by denying judicial enforceability to any class settlement before the summary judgment stage. ${ }^{17}$ They explain that litigants could not circumvent their proposal by agreeing in advance to "throw" the summary judgment motion and then settle collusively. ${ }^{118}$ Because that sort of illegal deal is of course unenforceable, there would be too great a risk that one party would defect; and this risk would deter the parties from entering into such an arrangement in the first place. ${ }^{119}$ The same concerns would stop litigants from staging sham trials if an opt-in system were adopted. The parties' uncertainty would be magnified by knowing that the outcome of a trial, unlike that of a settlement, is ultimately controlled by the court rather than by the colluders. And, whereas a court might approve an unfair settlement to clear the case off its docket, ${ }^{120}$ it has nothing to gain from accepting unfairness in the judgment. We could therefore expect collusion to diminish substantially, if not entirely, in an opt-in system. ${ }^{121}$

116. See Issacharoff, supra note 12 , at $829 \&$ n. 75 .

117. Kozel \& Rosenberg, supra note 111. Kozel and Rosenberg's proposal does not address the problem of collusion - just the problem of frivolous lawsuits.

118. Id. at 14-19.

119. Id.

120. See supra Part II.B.

121. Yet another objection that could be raised against the opt-in rule is the claim that I draw too sharp a distinction between adjudication and settlement. Those two forms of dispute resolution could be viewed as endpoints on a spectrum, rather than as the only choices in a binary system.

On this view, it might seem best to compromise between the current system and my proposal. We could, for example, retain the opt-out system and permit parties to settle, but only after a certain amount of discovery had been conducted. Such a proposal would reduce a judge's incentive to approve an unfair deal by forcing her to oversee part of the case before reviewing the deal.

But to reduce an incentive is not to eliminate it. So long as a judge knows that one decision (approving a settlement) will end the case whereas another decision (rejecting the settlement) will prolong the case, we cannot trust the judge to police the deal. Under such circumstances, the discovery itself would likely be a collusive sham because, unlike at adjudication, the parties retain control of the case's outcome. When a court is not charged with deciding the merits of a case, and the parties have 


\section{THE NATURE OF SETTLEMENT}

Class action collusion results from our failure to treat class settlements as the things they are: contracts. Courts use principles of contract law to protect parties to ordinary settlements, but our civil justice system has neglected to extend those principles to class settlements. Until we cure that neglect, we will continue to incur the social costs it creates.

The federal Constitution establishes courts to resolve "cases" and "controversies." 22 Every lawsuit thus invokes the power of the government to decide which side's argument is better supported by established law. ${ }^{123}$ But courts rarely make such decisions: "Over ninety percent of all cases (both civil and criminal) are currently settled." 124

A settlement is simply "[a]n agreement ending a dispute or lawsuit." 125 Unlike an adjudication, it is not a product of public decisionmaking or an expression of the legal principles that would have been applied to the merits of the dispute at trial. ${ }^{126}$ Instead, its character is principally that of a private contract in which one party relinquishes its right to litigate in return for something of value from the other party. ${ }^{127}$ Therefore, "normal rules of contract construction apply to interpretation of settlement agreements." 128 When an agreement has been reached, it may be challenged not on the ground that it is wrong or unfair, but only "where there is a claim of lack of actual consent or a lack of subject matter jurisdiction.... [A] decree that 'appears by the record to have been

the opportunity and the motivation to collude, the result is easy to predict. Collusion would surely persist in such a system.

122. U.S. CONST. art. III.

123. See Owen M. Fiss, The Forms of Justice, 93 HARV. L. REV. 1, 36-37 (1979) ("[T] he function of courts under the common law was paradigmatically ... to give meaning to public values through the enforcement and creation of public norms, such as those embodied in the criminal law and the rules regarding property, contracts, and torts. The courts created our law. They were the central lawmaking institutions. The judicial function implied by contemporary constitutional litigation ... is continuous with and maybe even identical to that of the common law. The issues have changed, and so has the social setting; that has required a change in the form of adjudication, though not its function.").

124. Carrie Menkel-Meadow, For and Against Settlement: Uses and Abuses of the Mandatory Settlement Conference, 33 UCLA L. REV. 485, 502 (1985).

125. BLACK's LAW DiCTIONARY 1377 (7th ed. 1999).

126. Of course, the parties might be influenced by the likely outcome of a trial-and, in turn, by the laws affecting that outcome-when they negotiate the terms of the settlement. See Robert H. Mnookin \& Lewis Kornhauser, Bargaining in the Shadow of the Law: The Case of Divorce, 88 YALE L.J. 950, 966 (1979). But this in no way imbues the settlement with the public character we attribute to an adjudication. See Owen M. Fiss, Against Settlement, 93 Y ALE L.J. 1073, 1085 (1984).

127. E.g., In re Omni Video, Inc., 60 F.3d 230, 232 (5th Cir. 1995) ("As we have held in federal diversity suits, a settlement is a contract and is best resolved by reference to state contracts law."); Janneh v. GAF Corp., 887 F.2d 432, 436 (2d Cir. 1989) ("A settlement is a contract, and once entered into is binding and conclusive."), overruled on other grounds by Digital Equip. Corp. v. Desktop Direct, Inc., 511 U.S. 863 (1994); see also KATHERINE V.W. STONE, PRIVATE Justice: ThE LAw OF ALTERNATIVE DISPUTE RESOLUTION 176 (2000) ("[A] settlement is a consensual rather than an imposed resolution of a dispute.").

128. Press Mach. Corp. v. Smith R.P.M. Corp., 727 F.2d 781, 789 (8th Cir. 1984) (citing Roberts v. Browning, 610 F.2d 528, 533 (8th Cir. 1979)); accord, e.g., Republic Res. Corp. v. ISI Petroleum, 836 F.2d 462, 465 (10th Cir. 1987) ("We construe a settlement stipulation in the same manner as a contract to determine how it should be enforced."). 
rendered by consent, is always affirmed, without considering the merits of the cause." 129

We thus treat ordinary settlements as contracts. We do not, however, currently treat class settlements as contracts. As the Supreme Court recently stated, "a valid contract requires offer and acceptance of its terms." 130 Let us assume that the defendant in a class action brought under Rule 23(b)(3) "offers" the terms of a settlement to absent class members by arranging, along with the plaintiff and the court, to notify them of the proposed deal. ${ }^{131}$ These notification letters will tell the class members that they will be included in the deal unless they reply and indicate their desire to be excluded. When class members do not reply, does their silence constitute acceptance? Under contract law, the answer would be no:

So fundamental is the tenet that mere silence is not acceptance that, even as the master of the offer, the offeror is powerless to alter the rule. The seller cannot turn the buyer's silence into acceptance by adding to the offer, "If I do not hear from you in a week, I will take it that you have accepted my offer." 132

Karl Llewellyn took the view that it would be "almost lewd" for our system to let one person transform another's silence into acceptance through the terms of the contract. ${ }^{133}$ As expressed in the comments to the Restatement (Second) of Contracts, "The mere receipt of an unsolicited offer does not impair the offeree's freedom of action or inaction or impose on him any duty to speak." 134

These statements may well put the point too strongly. Contract law can accommodate scenarios in which it makes sense to treat silence as acceptance, either because of past dealings between the parties or because the context surrounding the transaction makes clear that acceptance is intended. But those sorts of reasons are absent when a class member receives unsolicited mail and throws it out. If that type of silence gave rise to a contract, then merchants could flood the public with

129. United States v. Bechtel Corp., 648 F.2d 660,663 (9th Cir. 1981) (quoting Swift \& Co. v. United States, 276 U.S. 311,324 (1928)) (emphasis added).

130. Barnes v. Gorman, 536 U.S. 181, 186 (2002).

131. Even this much might be problematic, because it is typically the named plaintiff-not the defendant-who sends the notice letters. See, e.g., Eisen v. Carlisle \& Jacquelin, 417 U.S. 156, 173 (1974). Because the contractual relationship is between each absent class member and the defendant, it is strange to conceive of the "offer" being sent by a fellow plaintiff. And because the absent class members never hired the class's lawyer, that lawyer cannot be deemed their "agent."

132. 1 E. Allan FARNSWORTH, FARNSWORTH ON CONTRACTS 280-81 (3d ed. 2004); accord J.C. Durick Ins. v. Andrus, 424 A.2d 249, 250 (Vt. 1980).

133. Karl Llewellyn, Our Case-Law of Contract: Offer and Acceptance (pt. 2), 48 YALE L.J. 779, 801 n.35 (1939).

134. Restatement (SeCOND) of Contracts $\$ 69 \mathrm{cmt}$. a (1981); see also Peter Bowal, Comment, Reluctance to Regulate: The Case of Negative Option Marketing, 36 AM. Bus. L.J. 377, 381-82 (1999) ("The United Nations Convention on Contracts for the International Sale of Goods follows this common law position: 'A Statement made by or other conduct of the offeree indicating assent to an offer is an acceptance. Silence or inactivity does not in itself amount to acceptance."'). 
letters informing them that, unless they reply, they will be bound by whatever agreement the letter contains. ${ }^{135}$ Just as we have insufficient reason to think that the recipient of a mass mailing desires to accept the proffered deal, we do not learn from a class member's silence whether she prefers to be included in the settlement. ${ }^{136}$

The law of contracts provides a more hospitable environment for class settlements than might initially be thought. Excluding silent class members from these agreements does not leave those people emptyhanded. In an opt-in system, class settlements would likely be replaced by class adjudication, ${ }^{137}$ which can be expected to yield more for deserving class members than would a collusive settlement. Even if a given class action were to settle, individuals who are left out could form their own class and sue accordingly; and this scenario, too, might well be more promising than the initial settlement. ${ }^{138}$ More generally, an appealing point of contract law is that it trusts, and therefore empowers, the individual herself to decide whether. she would benefit from a proposed exchange.

Unlike an ordinary contract, a class settlement must be approved by a court. But such approval does not transform the agreement into an adjudication: A court will approve a class settlement so long as the settlement is "fair, reasonable, and adequate," 139 and "[i]n determining the adequacy and reasonableness of the proposed settlement, the court does not adjudicate the dispute."140 In adjudication, the court bears full responsibility for ensuring that the outcome is correct under prevailing law..$^{141}$ When a court approves a class settlement, by contrast, it decides in essence that the deal is "good enough." The Seventh Circuit, for example, approved a class settlement on the ground that, "at the time of the district court's approval of the settlement agreement, the desegregation plan contained in it did not initiate or authorize any clearly unconsti-

135. See Dennis D. Lamont, Comment, Negative Option Offers in Consumer Service Contracts: A Principled Reconciliation of Commerce and Consumer Protection, 42 UCLA L. REV. 1315, 1321-22 (1995) ("Congress passed the Postal Reorganization Act of 1970, essentially converting any unordered merchandise delivered to a customer's home into a gift and prohibiting sellers from trying to collect payment for it.").

136. Epstein v. MCA, Inc., 50 F.3d 644, 667 (9th Cir. 1995), overruled on other grounds by Matsushita Elec. Indus. v. Epstein, 516 U.S. 367 (1996); Eisenberg \& Miller, supra note 7, at 40.

137. See supra Part III.A.

138. See Mark Friedman, Note, Constrained Individualism in Group Litigation: Requiring Class Members to Make a Good Cause Showing Before Opting Out of a Federal Class Action, 100 YALE L.J. 745, 753-54 (1990).

139. FED. R. CIV. P. 23(e)(1)(C).

140. Parker v. Anderson, 667 F.2d 1204, 1209 (5th Cir. 1982); see also Young v. Katz, 447 F.2d 431, 433 (5th Cir. 1971) ("[In] examining a proposed compromise . . the court does not try the case. The very purpose of the compromise is to avoid the delay and expense of such a trial."); Henderson, supra note 80 , at 1021 .

141. See Fiss, supra note 124, at 1085 ("Their job is not to maximize the ends of private parties, nor simply to secure the peace, but to explicate and give force to the values embodied in authoritative texts such as the Constitution and statutes; to interpret those values and to bring reality into accord with them."). 
tutional activities."142 If the court had been adjudicating the case, it would have decided whether the Constitution was being violated, not merely whether it was being clearly violated. It therefore comes as no surprise that the Supreme Court has emphasized the gap between (a) an agreement that "might survive a Rule 23(e) fairness hearing" and (b) "the best possible arrangement for the ... class." 143

A court can be trusted to protect the absent class members at adjudication because its information and incentives are far better suited to that role than they are to the review of settlements. At the point of adjudication, the court will have heard considerable evidence and testimony on both sides. And at that point, neither outcome will reduce the court's workload and therefore receive potential favoritism.

The unifying idea behind these points is that adjudication is rooted in a different source of legitimation from that of settlement. The law requires people to honor the terms of a contract or settlement mainly because they consented to those terms. ${ }^{144}$ An adjudication, by contrast, is not predicated upon consent. ${ }^{145}$ Segregationists made clear that they did not accept Brown v. Board of Education ${ }^{146}$ and its progeny, but their views did not release them from the duty to abide by those judgments. Someone who is sued will be bound by an adjudication even if he refuses ever to come to court and represent himself. ${ }^{147}$

Like a contract, a settlement is an instrument of ordinary interaction between individuals. An adjudication, on the other hand, is paradigmatically public. In order to bind people without their consent, a judgment relies on the legitimizing force that our constitutional system gives it. ${ }^{148}$ Because the Constitution imbues courts with the power to resolve cases, and because it further bolsters the legitimacy of courts by ensuring that judges are appointed by politically accountable officials, we trust the judicial branch to render decrees that must be honored. Because a settlement lacks such legitimizing force, it requires consent as a substitute. Our legal system thus has no clear ground on which to demand adherence to the terms of a settlement, such as a class settlement, in the absence of consent. ${ }^{149}$

142. Armstrong v. Bd. of Sch. Dirs., 616 F.2d 305, 322 (7th Cir. 1980) (emphasis added).

143. Ortiz v. Fibreboard Corp., 527 U.S. 815, 852 (1999).

144. E. Allen Farnsworth, FARNSWORTH ON CONTRACTS $\$ 4.16$ (3d ed. 2004).

145. See Cooper, supra note 22 , at 936.

146. 347 U.S. 483 (1954).

147. FED. R. CIV. P. 55.

148. See Owen M. Fiss, Out of Eden, 94 YALE L.J. 1669, 1673 (1985) ("Adjudication is more likely to do justice than conversation, mediation, arbitration, settlement, rent-a-judge, mini-trials, community moots or any other contrivance of ADR, precisely because it vests the power of the state in officials who act as trustees for the public, who are highly visible, and who are committed to reason.").

149. See Fiss, supra note 127, at 1085 ("Adjudication uses public resources, and employs not strangers chosen by the parties but public officials chosen by a process in which the public participates. These officials, like members of the legislative and executive branches, possess a power that has been defined and conferred by pubic law, not by private agreement."). 


\section{CONCLUSION}

We have lived with collusive class settlements for too long. Judges simply cannot be forced to police such settlements, and the incentive to clear the docket makes it unlikely that they will accept the policing role willingly. Even if they did, they would be hamstrung by the adversarial void and by the absence of evidence brought to light through discovery.

Treating a class settlement in the same manner as any other settlement - as a simple contract - might well bring an end to class action settlements altogether. Only the few class members who opt in would be part of the settlement and thereby precluded from filing their own lawsuits. Plaintiffs' lawyers could no longer receive large contingent fees through settlement, because the settlement amount would be small. Defendants could no longer insulate themselves from all future lawsuits by settling. Adjudication would therefore replace settlement as the typical resolution of class lawsuits, thereby putting an end to collusive agreements. Although this change would cause courts and parties to incur the costs of litigation, those costs would be mitigated by the new disincentive for plaintiffs to bring frivolous lawsuits.

Class actions are perhaps as divisive an issue as there is in civil procedure. ${ }^{150}$ Many see these lawsuits as a tool used by greedy and unscrupulous plaintiffs' lawyers to extract money from deep-pocketed corporations that have done nothing wrong-a tool that imposes costs, in turn,

Indeed, the Supreme Court has cast doubt on the notion that class settlements should have the power to bind those who do not consent. In Martin $v$. Wilks, the Court addressed a case in which the NAACP had previously brought a class action against the city government of Birmingham, Alabama, for racial discrimination in public hiring practices. 490 U.S. 755, 759 (1989). That case had settled, and in the settlement the city had agreed to pursue certain benchmarks for the hiring and promotion of black firefighters. Id. When the city implemented this plan, white firefighters brought a lawsuit of their own, claiming that the plan violated their civil rights. Id. at 759-60. The city argued that the white firefighters should be barred from filing suit because they did not intervene in the initial lawsuit. Id. at 762. The Supreme Court ruled, however, that the white firefighters were not precluded from bringing suit. Id. at $762-63,769$. The Court reasoned as follows:

A voluntary settlement in the form of a consent decree between one group of employees and their employer cannot possibly "settle," voluntarily or otherwise, the conflicting claims of another group of employees who do not join in the agreement. This is true even if the second group of employees is a party to the litigation: " $[\mathrm{P}]$ arties who choose to resolve litigation through settlement may not dispose of the claims of a third party ... without that party's agreement. A court's approval of a consent decree between some of the parties therefore cannot dispose of the valid claims of nonconsenting intervenors."

Id. at 768 (emphasis added).

The outcome of Martin v. Wilks does not, as a matter of doctrine, contradict the current practice of binding absent class members by the terms of a settlement to which they never consented. Despite the italicized dictum in the above quotation, the white firefighters in Wilks were not parties to the original class action; whereas absent class members are parties to the class action whose settlement binds them. But to rely upon that distinction is to elevate form over substance. The reason it matters that the white firefighters were not parties to the original action is that requiring them to intervene places a burden on them that they should not have to shoulder. Id. at 763-64. Even if they know of the lawsuit, it would be unfair to require them to take affirmative steps to protect their rights. Id. at 765 . The same reasoning applies with equal force to absent class members when, as in Wilks, a class action settles.

150. See Monaghan, supra note 108 , at 1149. 
on consumers and employees. ${ }^{151}$ Others see class actions as a rare and valuable means of leveling the playing field between such corporations and the individuals they harm or exploit. ${ }^{152}$ Those in the first camp urge measures that would make class lawsuits more difficult or less lucrative for plaintiffs' lawyers, whereas those in the second camp resist such measures.

Such disagreements mask, however, a more basic common ground. Most courts and commentators presumably favor meritorious class lawsuits while disfavoring frivolous ones. They simply disagree about the relative prevalence and importance of the two sorts of cases. Up to this point, the academic and jurisprudential clashes have concerned issues where a policy choice would either encourage or burden both frivolous and meritorious class actions. ${ }^{153}$ The opt-in proposal presented here, by contrast, seeks to discourage the frivolous while enhancing the meritorious. It discourages plaintiffs' lawyers from bringing frivolous lawsuits because it conditions their reward upon success at trial, and it benefits class members with meritorious claims, because they receive the fair outcome of adjudication rather than the rigged outcome of class settlement. Defendants who have done nothing wrong will benefit from the new disincentive for plaintiffs to sue them without justification, whereas defendants who have wronged large numbers of people will be held more accountable.

151. See Coffee, supra note 8 , at $371-72$ ("Correspondingly, where the plaintiffs' attorney was once seen as a public-regarding private attorney general, increasingly the more standard depiction is as a profit-seeking entrepreneur, capable of opportunistic actions and often willing to subordinate the interests of class members to the attorney's own economic self-interest."); Green, supra note 112, at 1775 ("More practically, from the defendants' perspective, class actions are the ultimate weapon of legal terrorism, launched by litigation-mad, bottom-feeding, money-hungry, professional plaintiffs' lawyers.").

152. E.g., Lahav, supra note 11, at 70.

153. Notice requirements are a classic example. See Eisen v. Carlisle \& Jacquelin, 417 U.S. 156, 173 (1974); Mullane v. Cent. Hanover Bank \& Trust Co., 339 U.S. 306, 314-15 (1950); Marcus, supra note 9, at 889; Stephen C. Yeazell, The Past and Future of Defendant and Settlement Classes in Collective Litigation, 39 ARIZ. L. REV. 687, 697 (1997) ("In fact, within the plaintiffs' bar this [notice] requirement is seen with deep suspicion, as a procedural hurdle erected chiefly for the purpose-or at any rate with the predictable result - of making impossible many claims that might be both meritorious and viable were it not for this requirement."). 